\title{
Learning strategy implementation of jigsaw to upgrade the academic competency of counselor candidate
}

\author{
Devi Permatasari ${ }^{*}$ \\ Educational Faculty, Guidance and Counseling Program, Kanjuruhan Malang University \\ *) Corresponding author, $\equiv$ e-mail: devipermatasari.unikama@yahoo.com
}

\begin{abstract}
Peculiarly, the building of academic competency on counselor candidate needs to be gained through activity degree and student learning outputting class. Student academic competency in work skill on guidance and counseling course, notably in management and evaluation of guidance and counseling course require for having knowledge on theoretic treasures, context, principle, procedure and tools used in performing guidance and counseling service, also in developing professionalism as counselor on an ongoing basis by practicing guidance and counseling performance procedurally in school. Academic competency that will be gained by student can be categorized in three aspects of academic competency accomplishment, which are cognitive, affective, and psychomotor. The researcher concludes that the lack of those three aspects above caused by the learning process in class which is expository, that giving less attention on learning experience organization. So, the study content tends to be forgotten easily. The using of jigsaw learning is expected to facilitate e-learning experience organization of the student in improving academic competency of counselor candidate. Classroom action research is implemented in three cycles. The result gained in each cycle is increase gradually. Cycle I shows that the development of student academic competency is still on low rank, cycle II shows medium average development of student academic competency, cycle III shows that the average development of student academic competency is on high rank. The implementation this learning strategy can be used to improve the learning process by prioritizing on academic competency through study activity and learning output of the student. As the process improvement, the researcher focuses on student learning, so that the lecturer has the role as facilitator only.
\end{abstract}

Keywords: Academic Competency, Jigsaw learning, Counselor Candidate

How to Cite: Permatasari, D. (2017). Learning Strategy Implementation of Jigsaw to Upgrade the academic Competency of Counselor Candidate. Couns-Edu: International Journal of Counseling and Education, 2(1): pp. 1118. DOI: $10.23916 / 002017023910$

\section{Introduction}

First degree (S1) Guidance and Counseling education program of University of Kanjuruhan Malang is one of the Education Institutions on Pedagogical Force(LPTK) under the Coach Association of University Education Institution which has capability to think of and intense skill to be source of reference to development and implementation of science, technology, and art in field of Guidance and Counseling. It can be stated that each education department is required to have competency in each field. According to Curriculum Center of National Education Ministry in Lasan (2014), competency defined as knowledge, skill, and principle values reflected on the habit of thinking and acting. This statement can be deepened by 
referring on The Minister Regulation of National Education number 27/2008; first degree education (Scholar) for counselor candidate is carried out to prepare in mastering the counselor competency, specifically on academic competency by applying the rule of learning process for the counselor candidate. The learning process rules for counselor candidate include how the learning process can be performed in order to enable the student acquire various experience, that are (1) acquiring and integrating knowledge, expanding and refining knowledge, applying knowledge meaningfully, (2) acquiring skill of cognitive personalsocial and psychomotoric, and also (3) developing attitude and value attitude on the basis of character building (ABKIN, 2007).

Peculiarly, the building of academic competency on counselor candidate needs to be gained through activity degree and student learning output in class. The higher of student activity on learning certainly resulted on the high output. Various researches that have been conducted show high correlation between study activity and the output. For the students of Guidance and Counseling study program who are prepared to be counselor candidates, in elementary schools until senior high schools, certainly they have to possess academic competency which can be developed through their experiences according to the rules of learning for the counselor candidate which afterwards can become basic competency for professional counselor. It means that students not only have comprehensive understanding toward multiple courses, but also have actual experience in their study activity. From several work skill courses, there are courses that prepares the students to have academic competency which expected to be acquired and applied, that are Management of Guidance and Counseling and Evaluation Guidance and Counseling. The substance of these courses are more to mastery of basic theory in the meaning of acquiring and integrating knowledge, expanding and refining knowledge, applying knowledge meaningfully, acquiring skill of cognitive and personalsocial. These courses are also able to create professional counselor that can give service to the counselee.

Keep in mind that academic competency cannot be aside from aspects of cognitive, affective and psychomotor which become objective achievement standard in conducting Guidance and Counseling learning process. If these three aspects of BK learning objective can be achieved well, then socially, the counselor candidate able to build solidarity and strong emotional bonding with fellow students at the same year or fellows from other years as the fellow generation of BK education. At the end of study process, the counselor candidates are able to remove their dependences on the lecturer and able to reconstruct their knowledge by themselves correctly and directivity, making decision wisely, having initiative, and capable to innovate (Harahap, 2006). On the basis of cognitive aspect, the counselor candidate expected to have capability of synthesis analysis based on strong mastery of theory. Nevertheless, in some courses the students don't have the capability of synthesis analysis in mastering the basic theory of Guidance and Counseling yet. It can be seen from the observation conducted by students from the generation of 2015during September until November 2015on some courses. The observation result shows that the skill of synthesis analysis in mastering the basic theory of Guidance and Counseling is on low level.

Some gained data that shows the low level of students activities of counselor candidate are (1) too picky in choosing friends as the members of study group,(2) pretend to be nice towards disfavor friends when having interaction, (3) doing the group tasks by dividing based on the number of students and then accomplish them by their own self, put the tasks together without discussing, so that each of them responsible for their own tasks (4) disregard toward friends that giving their opinion or presentation (5) judging friends by their physical appearances only, (6) busy with their own business while the lecturer is explaining the subject in front of the class, (7) the students tend to be passive and quiet when the lecturer is giving question, and (8) students tend to be satisfied quickly with the answers given by fellow students that are giving the material of class presentation.

In fact, in the learning process inside the class showed that the active study level occurred on some students. Based on the observation of learning process, only around $20-30 \%$ of the students who were active in the course and the rests were quiet, only listened to and scrutinized the explanation from lecturer or friend. Moreover, there were some students who busy with their own activity that made them couldn't catch up the lecture well, such as talking with their friend next to them or playing with their communication tool. It happened continuously, although the lecturer had motivated and gave them chances to ask, to answer the questions, or to give opinion, thought, ideas to solve problems emerged in 


\section{COUNS-EDU}

The International Journal of Counseling and Education

Vol.2, No.1, March 2017

the process of learning. This condition assumed to be occurred also in other courses. Based on the observation, some lecturers gradually tried to change their way of lecturing toward the way of learning centered to the students, at least it seen from giving more chances to the students to be more active in the learning process, such as group discussion, task appointment, field survey, and presentation by the students.

If this low level of active study cannot be solved quickly, then it would give furthermore consequence on passive students, uncritical, less responsibility, less responsive toward surroundings, easily influenced by the environment and having less social-emotional. It is predicted may cause not optimal competency achievement of university graduates. Besides the low level of study, another problem occurs, that is the study output in management and evaluation of guidance and counseling courses. Data shows that the average value of the students in that courses are 61-70 or B- (2.7). The low level of study and the output study of students cannot be separated from various influencing factors, such as internal factor, which comes from inside the self and external factor which comes from outside the student (Biggs \& Tefler, 1987; Winkel, 2007). Internal factors that influence the learning activity are attitude, motivation, concentration, intelligence quotient, and emotional quotient. Meanwhile, the external factors are learning material, learning source, learning environment, and learning method of the lecturer.

In relation with the low competency of student of counselor candidate in learning activity and the learning output, it assumed that the influencing factor came from the method teaching applied by the lecturer. All the time, the teaching method applied is by giving speech(expository), questions and answers, and group discussions (group presentations).Although question and answer method was applied, but in fact the questions came more from the lecturer and some active students, while the rests were passive. Likewise, in answering the questions, the lecturer was the one who more active. Besides that, the lecturer gave less attention and appreciation to the students who were brave and active in giving questions and opinion. On the other side, when a student asked question, instead of giving the answer to the whole class, the lecturer seemed to focus only to the one who asked and ignored the others. This made the learning interaction became two-way interaction (between lecturer and student or viceversa), which became ateacher centered-learning. On the other hand, the interaction expected to occur is multiple way learning interaction, which more student centered. The learning method of teacher centered that applied by lecturer most of the time was a dull method, made them sleepy. Therefore, this kind of learning method is less effective to be applied for the students.

Such kind of condition is very worrying for the students to be maintained as the learning method applied on university. Furthermore, it may result in descending competency of counselor candidate student. The learning method that center to the students (students centered) likewise cooperative learning method. Cooperative learning is a method of learning in small group. Students learn in groups which each group members has different skill. The number of member group consists of four to six students that work together in learning activity. The group is given rewards according to how much each member has learnt (Slavin, 2006).

Theoretically, cooperative learning is viewed to be able to develop academic achievement and nonacademic achievement as well, such as social relation, inter-personal, intra-personal and group cooperation. According to Arends (2014), cooperative learning is developed to achieve at least three main objectives; they are academic achievement, tolerance and acceptance to diversity, and development of social skill. Marning and Lucking (1991) stated that cooperative learning not only giving positive contribution to academic achievement, but also improving social skill and self-esteem of the students.

One form of cooperative learning is jigsaw method, which is in this research will examine the implication on the student competency of counselor candidate. On learning method of jigsaw,students learn in groups which consist of students with heterogeneous skill and each of them is responsible for one part of the learning material (Arends, 2014). The learning topic is given by the lecturer, meanwhile the students tasks are to study carefully the topic and discuss various material in expert group, then share that material on original group (sharing).

Aronson, et al (Marning and Lucking, 1991) through the research concluded that students taught by jigsaw method, became more interested in their friends in same study group than their interest in friends of 
same class which from different study group. By cooperative learning, they became more appreciate to each other and care one another, so that able to improve interpersonal relationship between them. ChunYen and Song-Ling (1999) observed the impact of jigsaw method on academic performance and nonacademic performance of high school students that study natural science. One of the student groups is placed randomly, taught by jigsaw method (experimental group) and other group was taught by traditional method (control group). The result showed that experimental group had higher academic performance, had less prejudice, and improved social relationship compared to the control group.

Gillies (2003), researched junior high school that learnt to solve the problem, accomplished tasks of mathematics, natural science, and English language in small structured group and unstructured group. 220 studentsof $8^{\text {th }}$ grade participated on the research, which conducted in 3 termin. Students worked in group consisted of four students, female and male, with heterogeneous skill. The result showed that students who studied in structured group were more cooperative and gave more help to each other when they study in a group compared to students that work in unstructured group. Moreover, found that students learned in structured group had strong perception that study in small group was very exhilarating and enabled them to gain opportunity to learn together with good quality.

Learning strategy of jigsaw is chosen because it has purposes not only to improve academic achievement but also to improve acceptance widely from people with diversified culture, social class, skill and weakness. Learning strategy of jigsaw giving opportunity for students from different backgrounds and condition to work together and involved positively. Being accustom to social skills is important thing to have as the provisions to development of counselor candidate competency.

\section{The competency of counselor candidate}

The Department of National Education (Depdiknas (2007), on the basis of task context and performance expectancy meant, the comprehensive characteristics of counselor cover academic competency and professional competency as one integrity. Academic competency of counselor candidate is scientific basic and arts of conducting professional service on guidance and counseling.

The academic competency of counselor candidate in rules of learning process cover the skills of (a) understanding counseli going to be served, (b) mastering the treasures of theoretical, context, principle, procedure, and tools used in conducting the service of guidance and counseling, (c) conducting independent service of guidance and counseling, and (d) developing professionalism as counselor continuously based on values and supportive personal tendency. The building of academic competency of counselor candidate is carried through formal education of grade S-1 in field of guidance and counseling.

Some efforts to support skill and competency which reflected on attitude and behavior of counselor required for:

1. The requirements of professional counselor candidate not only based on the minimum of education level but also emphasizes on personal requirements such as intelligence, talent, interest and other personal aspects that believed can be supportive to the profession.

2. The determination of education accreditation of counselor candidate and the handout of license or authority for a counselor as letter of credence (credentials) given by profession organization based on national standard needs to be carried out continuously.

3. The arrangement of the course not only emphasize on the course aspects but also has continuity between the courses and the conduction of practical work either in laboratory or in field.

4. Giving opportunity to practice and self-evaluation and also its development for the counselor that qualified to profession standardization should be conducted by ABKIN and institution where the counselor works at.

\section{The learning model of jigsaw in university to improve academic competency of counselor candidate}

Learning process that frequently practiced in university nowadays, most of it still applies the learning method of teacher centered, where the delivery form of teaching is one way face to face (speech). When attending course or listening to the speech, the students will meet difficulty in following or comprehending 


\section{COUNS-EDU}

The International Journal of Counseling and Education

Vol.2, No.1, March 2017

the essential meaning of learning material, so that their activities are limited only on making notes that the rightness is questionable. The pattern of learning process where the lecturer is active (teacher centered) and the students are passive has low effectiveness, and cannot develop active participation process in learning (Depdiknas, 2008). New paradigm of university learning process nowadays views that knowledge as the result of construction or formation of learning person. So that learning is a process to seek for and construct knowledge, actively and specifically. One of the constructive learning applied on university is cooperative learning (Depdiknas, 2008). One type of cooperative learning is jigsaw method, which is in this research will examine the implication on skills of interpersonal relationship and group cooperation. On the learning method of jigsaw, students work in group that has heterogeneous skills and each student has the responsibility on one part of material (Arends, 2014).

Firstly, Jigsaw was developed and tested by Elliot Aronson and his friends at Texas University, then adapted by Slavin and his friends at John Hopkins University (Arends, 2001). Students not only have to learn the material given, but also have to be prepared in teaching that material to the members of the group. Therefore, the students are depending on each other and have to work cooperatively to learn the material and task given. In this technique, the lecturer pays attention to schema or students experiences backgrounds and helps them in activating this schema so that the material learning become more meaningful. Jigsaw is designed for improving the sense of students responsibility on their own learning process and others learning process too. Jigsaw is a model of cooperative learning where students work in small groups consist of 4-6 members in heterogeneously and work together with positive dependence and responsibility on thoroughness part of learning material that has to be learnt and deliver that material to the rest group members (Arends, 2014).

The conduction steps of Jigsaw learning strategy, are as follows: first, the lecturer conveys the course competency that has to be acquired in one term; second, the lecturer forms groups and determines the group representatives in averages; third, the lecturer delivers the subjects or teaching material used according to the determination of group representatives; fourth, each group representative join in expert group; fifth, the students discuss and work through the expert group; sixth, the report to original group to explain the result of discussion in expert group; seventh, the lecturer encourages the group members to ask questions to the presenter and discuss the group work sheet; eighth, stabilizing and making conclusion over the material by the guidance of the lecturer; and ninth, individual evaluation and group rewards.

\section{Method}

This research use qualitative approach. The type qualitative research applied is classroom action research. Classroom action research is systematic observation, which is conducted by researching teacher, the headmaster, school counselor, or others who have authority to make policy on teaching learning environment to gain information about the school conduction, how they teach, and how good are the students have learnt (Mills, 2007).

The subject of this research is the students of Guidance and Counseling Department of University of Kanjuruhan Malang that are studying Management of Guidance and Counseling course on offering B 2015/2016 generation with 36 students. The next are students of Evaluation on Guidance and Counseling course at offering A 2013/2014 generation with 36 students.

This research is conducted through several steps, which are introduction study and arranging action plan. The activity of introduction study is conducted to gain sufficient data in order to formulate the needs. The next step is arranging action plan to be carried out in action cycle. The next is conducting the action, observation, and reflection of action result. If the case related to the objective of learning is not achieved, then the revision will be conducted on next cycle. The conduction of action on one cycle covers four steps, which are planning, conducting the action, observation, and reflection.

\section{Results and Discussions}

The research discovery on each cycle can be seen from the learning process. The learning process is also valued from the student commentary on each ending of the learning process. The research discovery 
on cycle I showed that the indicator defined by the researcher at the beginning plan of the research, cannot be achieved yet by the students. Students are just come to 'low' development of three aspects on academic competency achievement (Cognitive, Affective, and Psychomotoric). The conduction process of learning strategy on the research cycle I was not perfect yet, which was the less comprehension of material concept by the group representative caused the way in delivering the summary of material cannot be comprehended by the original group. Then, the rewards of student achievement were given in paper and not deliver them directly. Another weakness that obstructed the learning process was that in delivering the material to the group, student tended to read the text and the presenter couldn't deliver the material well, so that it made the other members more confused and not comprehend the explanation. It caused the student unable to comprehend three aspects of achievement on academic competency, but the student didn't realized that in discussion needed to pay attention on that three aspects of achievement on academic competency.

The research discovery on cycle II showed that, student had 'medium' development of three aspects on academic competency achievement. It was related to the conduction learning process of jigsaw on cycle II. According to data collection instrument, the observation and reflection process conducted, showed that jigsaw on cycle II has been conducted harmoniously and comprehensively. The lack development of three aspect of achievement on academic competency was assumed come from the students that were lack of confidence and conviction in delivering the material to group so that the students appointed each other to give the presentation firstly. Besides that, the weakness of this cycle was the students who depended on the conclusion of the material to the lecturer, so that the development of three aspects on academic competency achievement still obstructed.

The research discovery on cycle III showed that, the students were on 'high' development, which meant that the indicator defined at the beginning of research for three aspects on academic competency achievement of counselor candidate has been achieved. This was an improvement continuously from the result of each research. On cycle III, the companion lecturer as the researcher conducted the revision strategy applied on the learning process of jigsaw, by giving the material order to group representative, so that at the time of presentation, the original group had already each responsibility according to material order and chose the group leader so that the discussion would run smoothly directed by one in charge and minimalized the conflicts in the group. Besides that, they also chose a secretary to make notes and deliver the result of discussion in orderly, so that no more dependence on conclusion explanation to the lecturer. Remembering that the tasks of companion lecturer are only to correct the material and give rewards to students achievement in presenting the material with responsibility.

It is expected by the decreasing amount of conflicts that imply on effective conduction of, and the development of three aspects on academic competency achievement will increase. This is appropriate with preceding discovery about jigsaw. Jigsaw Model has two impacts in students, which are instructional impact and side impact. The impacts are on acquiring the concept, positive dependence, group processing, the awareness on diversity, collective leadership, tolerance on differences, and social sensitivity (Wibowo, 2010). The applying of this strategy may improve the learning process by emphasizing on academic competency through learning activity and the learning output. As the revision process, the researcher focuses on student learning, so that the lecturer only gives a role as the facilitator. Besides that, all students become active and involved in the learning process. Meanwhile, as the improvement result, students are able to improve the learning achievement according to three aspects on academic competency achievement. This is strengthened by the research result conducted by Wibowo (2010) which stated that student achievement in learning was influenced by jigsaw learning strategy.

Learning strategy of jigsaw has limitation such as the lecturer is required to prepare the material in written form to be discussed by the group in each course. Secondly, it requires the lecturer activity to check the evaluation result and to give commentary to the students individually. Third, it is hard to have the conduction in class with large amount of students. Fourth, student cannot reveal the full result of selfreflection and the process of learning due to the limitation of language skill in written and communication delivering the material individually. Fifth, sometimes the students discuss unrelated material so that 
wasting so many times on tiny things at the time of discussion. Sixth, the material coverage in each learning process is very limited. Seventh, students need sufficient time to discuss with expert group.

\section{Conclusions}

Class action research takes place in three cycles with the aim to improve academic competency of counselor candidate with three aspects of achievement in the learning process, that are cognitive, affective, and psychomotoric. Three aspects of achievement academic competency of counselor candidate also refers to the rules of learning process of counselor candidate that have been defined by ABKIN cover how to conduct the learning process that enable the students acquire various experience, which are (1) acquiring and integrating knowledge, expanding and refining knowledge, applying knowledge meaningfully, (2) acquiring skill of cognitive, personal-social and psychomotoric, also (3) developing attitude and value attitude on the basis of character building.

Thus, it can be concluded that the improving of academic competency through learning process is by using jigsaw learning strategy. In improving academic competency through three aspects of achievement is done continuously to reach defined indicators, which are: (1) cognitive, that include student knowledge in recollecting and studying the material content; student comprehension in explaining and concluding the material content; the student application in indicating problems are frequently occurs with school counselor, analyzing and organizing the problems; (2) affective, that include taking the explanation well; giving response to friends who ask questions by giving appropriate answers according to the comprehension and able to discuss it with the group; sharing ideas and considering friends input or opinion; (3) psychomotoric, that include listening other friends opinion well; practicing in making BK program and $\mathrm{BK}$ evaluation instrument in groups and individually; practicing the implementation on school; demonstrating what has been practiced in school with the group.

The effective jigsaw learning strategy in developing academic competency of counselor candidate is by doing the learning process continuously and well directed. This well directed aspect can be gained by appointing of the students as the group chief that leads and organizes the discussion of the group, then appointing one of them as group secretary in order to make the conclusion of the whole material easily. By applying this strategy students are able to involve actively in the whole process of learning, without conflicts on the order of presentations, so that it may give valuable experience for the students.

By choosing the right learning strategy of jigsaw will give positive contribution to improve academic competency of counselor candidate. At the end of the cycle III, the students are able to improve three aspects of achievement on academic competency of counselor candidate on "high" level, although some students still having difficulties in delivering the material well.

\section{Acknowledgments}

We would like to thank to the university student who had participated in the lecturing start from beginning until the end.

\section{References}

Arends, R. (2014). Learning to teach. McGraw-Hill Higher Education.

Asosiasi Bimbingan dan Konseling Indonesia. (2007). Penjelasan Standar Kompetensi Konselor Indonesia dalam Konteks PP Nomor 19 Tahun 2005. Bandung: ABKIN.

Biggs, John B. dan Tefler, Ross. (1987). The Process of Learning. Sidney: Prentice Hall of Australia Ltd.

Chun-Yen Chang \& Song-Ling Mao. (1999). The Effects on Students'Cognitive Achievement When Using the Cooperative Learning Method in Earth Science Classroom. School Science and Mathematics, Volume 99. (Diakses dari Questia Media America. Inc. www.questia.com).

Depdiknas. (2007). Rambu-Rambu Penyelenggaraan BK dalam Jalur Pendidikan Formal. Jakarta: Ditjen PMPTK Depdiknas.

Depdiknas. (2008). Buku Panduan Pengembangan Kurikulum Berbasis Kompetensi Pendidikan Tinggi. Jakarta. Ditjen Dikti Depdiknas. 
Gillies, M. R. and Ashman, F. A. (2003). An historical review of the use of groups to promote socialization and learning. Cooperative Learning RoutledgeFalmer: London and New York.

Harahap, F. (2006). Menumbuhkembangkan Karakter Konselor Profesional: Menuju Tradisi untuk Dinilai. Paradigma. 25 (1): 9-12.

Lasan, B. B. (2014). Konselor Sekolah: Tinjauan dan Upaya Profesionalisasi. UM: Elang Mas.

Marning, M. L. \& Lucking, R. (1991). The What, Why and How of Cooperative Learning. Social Studies, Volume 82. (Diakses dari Questia Media America. Inc. www.questia.com).

Mills, G.E. (2007). Action Research: A Guide for the Teacher Researcher ( $3^{\text {th }}$ Ed.). New Jersey: Pearson.

Slavin, R.E. (2006). Educational Psychology: Theory And Practice (Edisi ke-8). Boston: Pearson

Wibowo, L, A. (2010). Pengaruh Metode Cooperative Learning Teknik Jigsaw terhadap Prestasi Belajar Mahasiswa. Jurnal UPI. (Online), 6(17), (http://jurnal.upi.edu/189/view/260/pengaruh-metodecooperative- learning-teknik-jigsaw-terhadap-prestasi-belajar-mahasiswa.html), diakses 2 Januari 2017.

Winkel, WS. (2007). Psikologi Pengajaran. Yogyakarta: Media Abadi. 